\title{
Short communication: Changes in the composition of yak colostrum during the first week of lactation
}

\author{
J. D. Mi, ${ }^{*}$ J. W. Zhou,† L. M. Ding, ${ }^{*}$ L. Wang, $†$ and R. J. Long*1 \\ *School of Life Sciences, Institute of Arid Agroecology, and \\ †College of Pastoral Agriculture Science and Technology, State Key Laboratory of Grassland Agro-Ecosystem, International Centre \\ for Tibetan Ecosystem Management, Lanzhou University, Lanzhou 730000, PR China
}

\section{ABSTRACT}

Although the great interest has been paid to colostrum utilization for calves, no systematic studies evaluating the compositional changes of yak colostrum during the first week after parturition have been reported. The aim of this study was to elucidate such postpartum nutritional changes. Colostrum samples from 12 multiparous (2-7 lactations) yaks, grazed on alpine pasture, were collected at exactly 1, 24, 48, 72, 96, 120, 144, and $168 \mathrm{~h}$ postpartum. Gross composition (fat, total solids, protein, and ash) were measured, as well as fat and water-soluble vitamins, fatty acid and mineral composition, and IgG. The colostrum, collected $1 \mathrm{~h}$ postpartum, had the highest concentrations of crude protein, total solids, ash, vitamin A and E, $\beta$-carotene, and most minerals $(\mathrm{Na}, \mathrm{Mg}, \mathrm{Zn}, \mathrm{Cu}$, and $\mathrm{Fe}$ ). These components decreased rapidly within $24 \mathrm{~h}$. Similarly, at $24 \mathrm{~h}$ postpartum, IgG content decreased to $7.5 \%$ of the value $(87.78 \mathrm{mg} / \mathrm{mL})$ at $1 \mathrm{~h}$ postpartum. In contrast, the concentration of vitamin $\mathrm{C}$ increased from 1 to $24 \mathrm{~h}$ and then decreased consistently thereafter to the lowest value at $168 \mathrm{~h}$. Phosphorus and Ca contents showed an increasing trend from 24 to 168 $\mathrm{h}$ after calving. Lactose content increased from $2.88 \%$ at $1 \mathrm{~h}$ to $4.96 \%$ at $48 \mathrm{~h}$ postpartum and was steady to $168 \mathrm{~h}$. Total n-3 fatty acids, monounsaturated fatty acids, polyunsaturated fatty acids, and n-3-to-n- 6 fatty acid ratio were proportionally similar as a percentage of total fatty acid methyl esters during the first $168 \mathrm{~h}$ of milk production. However, the proportion of total n- 6 fatty acid content to total fatty acid methyl esters decreased from $3.07 \%$ at $1 \mathrm{~h}$ to $2.60 \%$ at $24 \mathrm{~h}$. In summary, experimental results indicate colostrum should be provided to yak calves as soon as possible after birth to provide nutrients and enhance passive immunity.

Key words: yak colostrum, immunoglobulin G, vitamin, mineral

Received May 17, 2015.

Accepted September 13, 2015.

${ }^{1}$ Corresponding author: longrj@lzu.edu.cn

\section{Short Communication}

The mortality rate of yak calves is as high as $15 \%$, causing significant economic loss for local farmers (Wiener et al., 2003). Adequate feeding of colostrum or milk and proper feed management can help calves to establish passive immunity against disease and reduce casualties, particularly because colostrum and milk are the sole feed source for calves during the first $2 \mathrm{wk}$ (Long et al., 1999). Thus, comprehensive knowledge of the traits of yak colostrum is essential for its correct use or otherwise to develop an adequate colostrum replacer to guard against disease and calf mortality in the Qinghai-Tibetan plateau. A recent study investigated the gross composition, nitrogen fraction distribution, and AA and fatty acid profile of yak colostrum (Cui et al., 2014); however, the immunoglobulins, vitamins, and minerals also play important roles in calf health. Immunoglobulin $\mathrm{G}$ is around 80 to $95 \%$ of total immunoglobulin content in dairy cow colostrum, providing initial passive immunity for offspring in early life (Larson et al., 1980). Vitamin and minerals in colostrum are cofactors for enzymes and maintenance of gut functions in ruminants (Morrill et al., 2012). This vital protective capacity of colostrum starts to decline dramatically after birth as the epithelial cells of the small intestine in ruminants cannot internalize and transfer IgG to the blood after $24 \mathrm{~h}$ of life in cow (Castro-Alonso et al., 2008). Therefore, it is important to harvest and feed colostrum to calves soon after birth. Despite this, no studies have investigated the composition of yak colostrum within $24 \mathrm{~h}$ after birth. The objectives of our study were to update the chemical composition (fat, TS, protein, ash, vitamins, minerals, and fatty acid profiles) and $\operatorname{IgG}$ concentration of yak colostrum at 1 , $24,48,72,96,120,144$, and $168 \mathrm{~h}$ postpartum, and then to evaluate the effect of different lactation times on its composition.

This experiment was conducted in Wushaoling $\left(37^{\circ} 12.48^{\prime} \mathrm{N}, 102.8^{\circ} 51.70^{\prime} \mathrm{E}\right)$ Tianzhu County, Gansu Province, northwest China. All animal experimentation procedures were approved by the Animal Ethics Committee of Gansu Province, China. Colostrum was 
sampled from 12 multiparous White Tianzhu yaks in the same herd. The experimental yaks consisted of 4 second, 3 third, 2 fourth, 1 fifth, and 2 sixth parity. The experimental period lasted from April to May 2013. The growing season of pasture begins in June; thus, all animals were fed with the same dry grass. The pasture is an alpine meadow characterized by 2 dominant sedges (Carex qinghaiensis L. and Kobresia pygmaea; these consist up to $85 \%$ of total vegetation). Samples of colostrum were taken at exactly 1, 24, 48, 72, 96, 120,144 , and $168 \mathrm{~h}$ postpartum, frozen, and stored at $-20^{\circ} \mathrm{C}$ until analysis.

A sample of $50 \mathrm{~mL}$ of colostrum was freeze-dried to analyze TS, fat, ash, and minerals. Total solids were calculated by difference using the weight of samples before and after lyophilization (FreeZone Plus, Labconco, Kansas City, MO). Fat was determined, upon extraction, with diethyl ether for $5 \mathrm{~h}$ in a SOX500 Fat Analyzer (Jinan Hanon Instruments Co. Ltd., Jinan, China) according to AOAC International (1999); ash was subsequently analyzed. Approximately $1 \mathrm{~g}$ of each dried colostrum sample was digested for $4 \mathrm{~min}$ at $140^{\circ} \mathrm{C}$, at $14 \mathrm{~atm}$ in $5 \mathrm{~mL}$ of concentrated nitric acid (Suprapur grade; Merck Millipore, Billerica, MA) in an HA-MSP-8600 microwave digestion Extractor (Beijing Beifen-Ruili Analytical Instrument Group Co. Ltd., Beijing, China). The digested samples were diluted to $100 \mathrm{~mL}$ with ultrapure water, and then analyzed for $\mathrm{Na}, \mathrm{K}, \mathrm{Ca}, \mathrm{Mg}, \mathrm{Mn}, \mathrm{Cu}, \mathrm{Fe}$, and $\mathrm{Zn}$ using flame atomic absorption spectroscopy using a M6AA system (Thermo Fisher Scientific Inc., Waltham, MA). Phosphorus was analyzed using a colorimetric method (Fiske and Subbarow, 1925). Crude protein was analyzed by the Kjeldahl method and calculated using a factor of 6.38 for percent nitrogen to protein content. Lactose was analyzed according to the procedure described by Teles et al. (1978). Dry colostrum samples were accurately weighed (1 and $24 \mathrm{~h}: 150 \mathrm{mg}, 48-168 \mathrm{~h}: 250 \mathrm{mg}$ ) into headspace bottles with $1 \mathrm{~mL}$ of internal standard (4 $\mathrm{mg} / \mathrm{mL}$ of $\mathrm{C} 17: 0)$. Fatty acid methyl ester extraction was conducted following the procedures described by Sukhija and Palmquist (1988); FAME was analyzed by GC-MS on a GC-MS 6890N-5975C (Agilent, Wilmington, DE) under conditions described previously (Ding et al., 2013). A mixed standard of 37 fatty acids (Supelco 37 component, Supelco Inc., Bellefonte, PA) was used to identify individual fatty acids. Fat-soluble vitamins (vitamin A, E, and $\beta$-carotene) were extracted according to procedures communicated elsewhere (Eitenmiller et al., 2007) and determined by HPLC, as reported by Arnaud et al. (1991). Vitamin C was also analyzed by HPLC by the method described by Albalá-Hurtado et al. (1997). The concentration was calculated using standards bought from Sigma (R7882; T3376; 22040;
A5960; Sigma-Aldrich, St. Louis, MO); IgG was analyzed by E11-118 ELISA Kit (Bethyl Laboratories Inc., Montgomery, TX) according to the manufacturer's protocol. Considering changes in colostrum over time, we chose samples at $1,24,72,120$, and $168 \mathrm{~h}$ after parturition. The final dilution of samples were 1,000,000-fold for samples at 1 and $24 \mathrm{~h}$ and 100,000-fold for samples at 72,120 , and $168 \mathrm{~h}$.

Data were analyzed using SAS version 9.4 statistics software (SAS Institute Inc., Cary, NC). The effects of lactation on the composition of colostrum samples were evaluated by repeated measurements using the program's MIXED procedure. The Tukey's test was used to compare paired mean values of samples taken at different times with a significance value of $P<0.05$.

Mean values of TS, protein, fat, ash, and lactose, grouped by time from calving, are shown in Table 1. Protein, TS, ash, fat, and lactose were noticeably affected by lactation time $(P<0.05)$. The protein concentration at $1 \mathrm{~h}$ after parturition was higher than the other samples due to the high content of immunoglobulin (Godden, 2008). At $48 \mathrm{~h}$ of lactation, protein concentration decreased rapidly to $33 \%$ of the value at $1 \mathrm{~h}$, but after that no significant differences were observed, in agreement with published studies (Romero et al., 2013; Sánchez-Macías et al., 2014). At the time of the first milking, Kehoe et al. (2007) found $14.9 \%$ protein; similarly, Morrill et al. (2012) discovered $12.7 \%$ protein in colostrum from dairy cows. At birth, colostrum protein was previously shown to range from 10.5 to $16.5 \%$ depending on goat breed (Romero et al., 2013; Sánchez-Macías et al., 2014); thus, protein concentration is affected by breeds (Sánchez-Macías et al., 2014). Total solids and ash decreased from 1 to $24 \mathrm{~h}$ and then stabilized until $168 \mathrm{~h}$ postpartum. El-Fattah et al. (2012) observed that both parameters continued to decrease until reaching a value in normal milk at 14 d postpartum in Egyptian buffaloes and Holstein cows. Fat concentration in yaks tested varied during first 168 $\mathrm{h}$ after calving, in accordance with published results for goat colostrum (Romero et al., 2013). In contrast, yak milk lactose concentration increased over the test period, congruent with trends reported by Romero et al. (2013).

In general, the greatest changes in the yak gross colostrum composition occurred within $48 \mathrm{~h}$ after calving. However, the time in which yak colostrum reached levels in normal milk was earlier in the animals tested than those from in other reported studies (El-Fattah et al., 2012; Cui et al., 2014). Total solids, ash, and fat contents returned to normal yak milk by $24 \mathrm{~h}$, and protein and lactose returned to normal at $48 \mathrm{~h}$ postpartum compared with the results of yak milk in a previous study (Ma et al., 2013). 


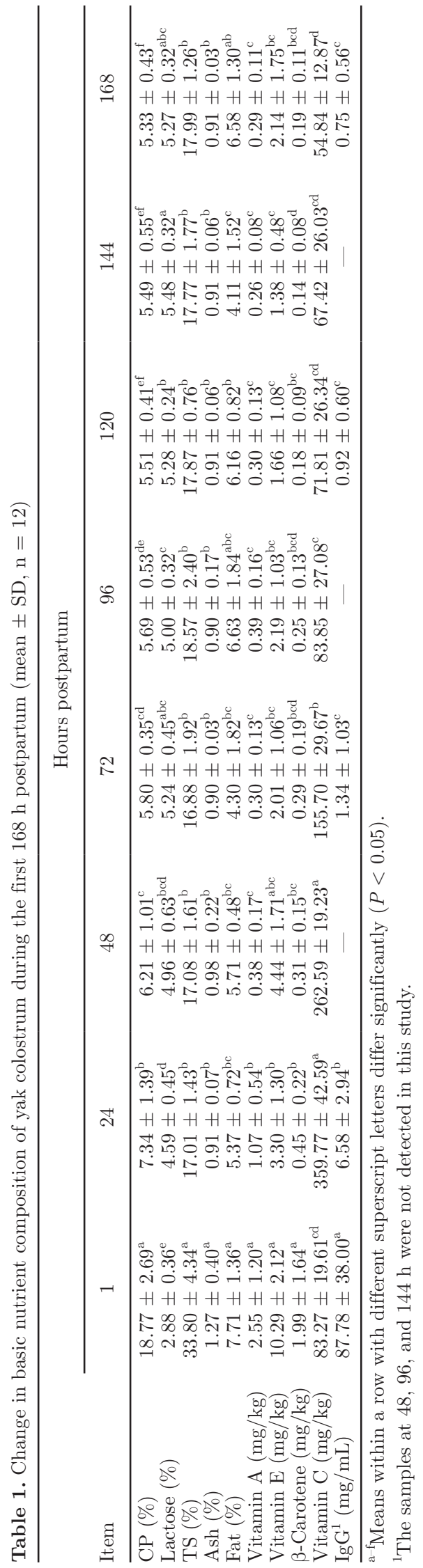

The reduction of IgG concentration in yak mammary secretions during the first $168 \mathrm{~h}$ postpartum, was best modeled by the equation: $\mathrm{y}=96.363 \mathrm{x}^{-0.954}$, where $\mathrm{y}$ is the concentration of $\operatorname{IgG}(\mathrm{mg} / \mathrm{mL})$ and $\mathrm{x}$ is the time postpartum (h; Table 1; Figure 1). At 1 and 24 $\mathrm{h}$ postpartum, the IgG concentrations were 87.78 and $6.58 \mathrm{mg} / \mathrm{mL}$, respectively, and reached a value below $1 \mathrm{mg} / \mathrm{mL}$ at $120 \mathrm{~h}$ postpartum. Similar to tested yaks in our study, Levieux and Ollier (1999) observed the highest IgG content in colostrum at the first milking of Holstein-Friesian cows. However, the rate of decrease within $24 \mathrm{~h}$ in tested yaks was greater compared with colostrum in dairy cows (Levieux and Ollier, 1999; Alves et al., 2015). Most of the IgG in colostrum occurs through postpartum transfer from maternal serum. As a result, the serum IgG concentration in cows is already decreased due to the extensive IgG transport into colostrum (Hurley and Theil, 2011). The differences might be a consequence of the different times of stoppage of postpartum IgG transport from serum to colostrum between yak and cow. Measuring antenatal and postpartum maternal serum IgG levels, as well as colostral antibodies in yaks and cattle, could further help elucidate such relationships.

Changes in vitamins $\mathrm{A}, \mathrm{E}, \mathrm{C}$, and $\beta$-carotene in yak colostrum during the first $168 \mathrm{~h}$ after calving are shown in Table 1. At $48 \mathrm{~h}$ of lactation, the concentration of vitamin A fell rapidly, to $15 \%$ of the value at $1 \mathrm{~h}$, and stabilized until the end of experimental period. The $\beta$-carotene and vitamin $\mathrm{E}$ concentrations of samples at $1 \mathrm{~h}$ were higher than that of all the other samples $(P<$ 0.05). At first milking, Foley and Otterby (1978) found $2.95 \mathrm{mg} / \mathrm{kg}$ of vitamin A in colostrum from bovines; Debier et al. (2005) reviewed the range of vitamin A

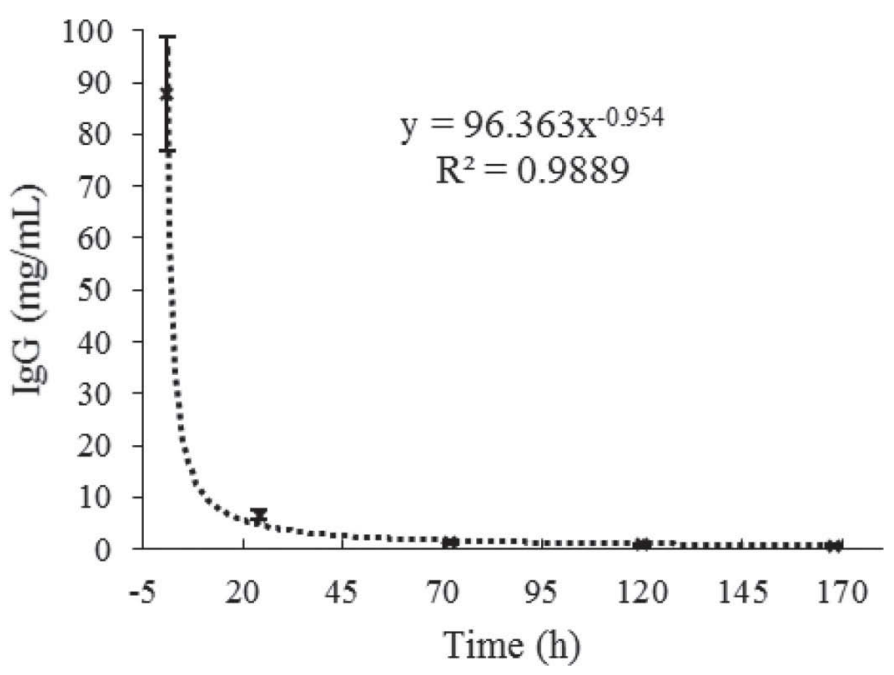

Figure 1. Changes in immunoglobulin G concentration with time (h) postpartum. 
$(2.33-3.69 \mathrm{mg} / \mathrm{kg})$ in colostrum from different animal species, and Kehoe at al. (2007) observed $4.9 \mathrm{mg} / \mathrm{kg}$ of vitamin $\mathrm{A}$ in the colostrum of dairy cows. The variation of vitamin A might be associated with different seasons, breeds, and feeds (Klimeš et al., 1986). The $\beta$-carotene content of yak colostrum was about 3 times higher $(2 \mathrm{mg} / \mathrm{kg})$ than those in the report of Kehoe et al. (2007). Yak colostrum at $1 \mathrm{~h}$ postpartum contained higher vitamin $\mathrm{E}$ than other studied species (Debier et al., 2005). Guo et al. (2014) found similar results through reviewing the different functional ingredients in yak mature milk compared with cow milk. As with $\operatorname{IgG}$, the higher concentration of functional nutrients in yak colostrum and milk than in dairy cows is potentially due to the concentration effect by lower yield volumes (Ding et al., 2013; Cui et al., 2014).

The declining trend of vitamins $\mathrm{A}$ and $\mathrm{E}$ after parturition was in agreement with El-Fattah et al. (2012); however, the decreasing rate and time to reach stable values were different between yak and other species. Foley and Otterby (1978) reported that vitamins A and E continued to decrease at sixth milking postpartum in cows. The changes of vitamins $\mathrm{A}$ and $\mathrm{E}$ might be a consequence of special breed and environmental effects (cold and forage deficient from November to May; Long et al., 2008).

Vitamin $\mathrm{D}\left(\mathrm{D}_{2}\right.$ or $\left.\mathrm{D}_{3}\right)$ was not detected in yak colostrum in $90 \%$ of samples collected. Because vitamin $\mathrm{D}$ (318 IU/d for a $45-\mathrm{kg}$ calf) is critical in calcium homeostasis, immune function, and cell differentiation and proliferation, it is necessary for dairy calves get it within the first 2 wk of age (NRC, 2001). The recommended requirements of dairy calves for vitamins A and $\mathrm{E}$ are $24 \mu \mathrm{g}$ and $1.74 \mathrm{mg} / \mathrm{kg}$ of BW, respectively (NRC, 2001). In the current study, vitamin A in yak colostrum was adequate for yak calves; in addition, $\beta$-carotene could be converted to vitamin A by animals. After $1 \mathrm{~h}$ of age, the content of vitamin $\mathrm{E}$ in colostrum was not enough for calves, additional vitamin E should be supplied according to the recommendation value in dairy calves (NRC, 2001).

Because ruminants cannot synthesize vitamin $\mathrm{C}$ until 2 to 3 wk of age, colostrum and milk supply most of the vitamin $\mathrm{C}$ during this period (Cummins and Brunner, 1991). In the present study, we found that vitamin C concentration at $1 \mathrm{~h}$ after parturition was $83.27 \mathrm{mg} / \mathrm{kg}$ and increased to $359.77 \mathrm{mg} / \mathrm{kg}$ at $24 \mathrm{~h}$. The variation between 1 and $24 \mathrm{~h}$ might have contributed to the different moisture content in these samples. At $168 \mathrm{~h}$ after parturition the concentration of vitamin $\mathrm{C}$ decreased to $54.84 \mathrm{mg} / \mathrm{kg}$, which was higher than the concentration of normal milk reported in goat $(12.9 \mathrm{mg} / \mathrm{kg})$, sheep (41.6 mg/kg), cow $(9.4 \mathrm{mg} / \mathrm{kg}$ ), and humans $(50 \mathrm{mg} /$ kg; Park et al., 2007).
Most fatty acid concentrations were not affected by lactation time (Table 2); however, the proportions of C4:0, C6:0, C8:0, and C10:0 increased by 31, 44, 56, and $46 \%$ at $48 \mathrm{~h}$, respectively, compared with the fatty acid concentration at $1 \mathrm{~h}$ postpartum, and then became stable after $48 \mathrm{~h}$ postpartum $(P<0.05)$, which is in agreement with previous reports (Marounek et al., 2012; Cui et al., 2014). Butyrate, C6:0, and C8:0 showed opposite changes compared with the results reported by Coroian et al. (2013) with buffalo colostrum. The proportion of C15:0 in yak colostrum fluctuated from 1 to $168 \mathrm{~h}$. However, at $24 \mathrm{~h}$ postpartum, the proportion of C14:0 decreased to $74 \%$ of value at $1 \mathrm{~h}$ postpartum, and was stable after $24 \mathrm{~h}$ postpartum. The concentration of short-chain fatty acids (C4 to C11) increased by $45 \%$ from 1 to $48 \mathrm{~h}$ postpartum and reached stable levels of about $7 \mathrm{~g} / 100 \mathrm{~g}$ of FAME, which appeared from $72 \mathrm{~h}$ in the previous report (Cui et al., 2014). The sums of SFA, MUFA, PUFA, medium-chain fatty acids (C12 to C17), long-chain fatty acids (C18 to C24), n-6, n-3, and n-9 in the yak colostrum were not affected by lactation times, which were different from the previous reports (Cui et al., 2014). However, the main n-6 fatty acid (cis-9,cis-12 C18:2) and n-3 fatty acid (cis-5,cis8,cis-11,cis-14,cis-17 C20:5) presented a decreasing trend after parturition $(P<0.05)$. Polyunsaturated fatty acids varied from 4.31 to $5.10 \mathrm{~g} / 100 \mathrm{~g}$ of FAME, which was consistent with the previous report in cow colostrum (Marounek et al., 2012) and higher than the previous report on yak colostrum (2.86 to $4.34 \mathrm{~g} / 100 \mathrm{~g}$ of FAME; Cui et al., 2014). The most important index, n-3-to-n-6 (0.37-0.44), was not affected by lactation period, which was in agreement with data of yak colostrum in the previous study (Cui et al., 2014).

All minerals of yak colostrum, except $\mathrm{Cu}$, were affected by lactation time $(P<0.05$; Table 3$)$. The highest concentrations of all minerals in yak colostrum were found at $1 \mathrm{~h}$ postpartum. The concentration of $\mathrm{Na}, \mathrm{Mg}$, and $\mathrm{Zn}$ decreased rapidly to the value at 24 $\mathrm{h}$ postpartum and then remained stable until the end of study period, which was in agreement with previous results (Kume and Tanabe, 1993). The concentration of $\mathrm{K}$ in yak colostrum decreased gradually until $48 \mathrm{~h}$ after calving, whereas the $\mathrm{Mn}$ and Fe were varied during the experimental period. However, the results showed that the concentration of $\mathrm{P}$ and $\mathrm{Ca}$ had an increasing trend from 24 to $168 \mathrm{~h}$, which contradicted previous studies (Kume and Tanabe, 1993) but was similar to the study with dairy cows by Csapo et al. (1996).

The concentrations of minerals at $1 \mathrm{~h}$ in yak colostrum after parturition were higher than those in the cow (Foley and Otterby, 1978; Kume and Tanabe, 1993), except Ca and Na which were lower. Specifically, the concentration of $\mathrm{Zn}(32.90 \mathrm{mg} / \mathrm{kg})$ was twice as 


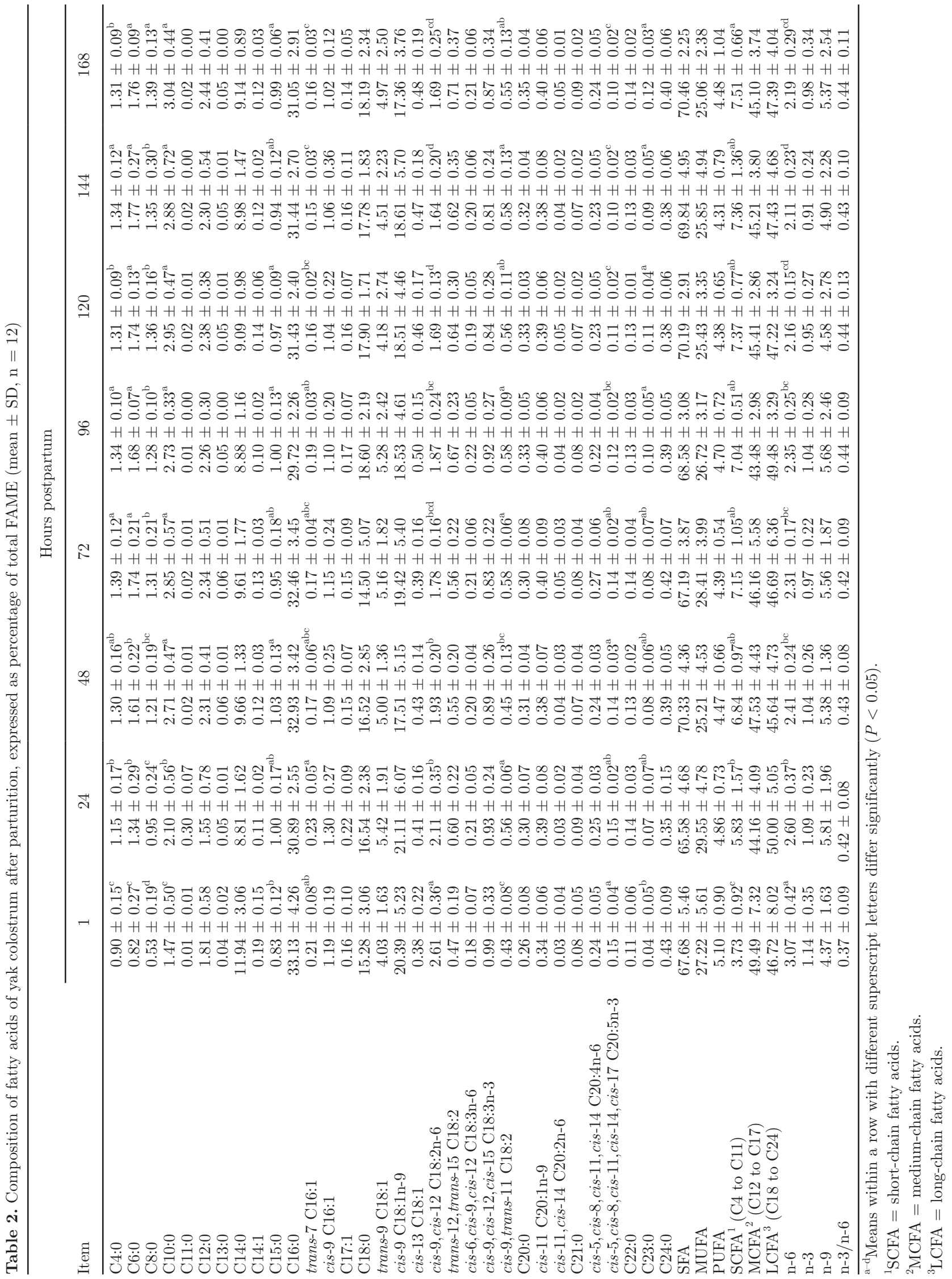


much and $\mathrm{Cu}(1.09 \mathrm{mg} / \mathrm{kg})$ was 9 times higher than that reported of Holstein cattle by Kume and Tanabe (1993; Table 3). However, the concentrations of all minerals in our study were lower than reported by Kehoe et al. (2007) in dairy cattle, except microelements $\mathrm{Cu}$ and Mn. The variation might be a consequence of differences in nutritional management and breeds. The concentration of $\mathrm{P}, \mathrm{Mg}$, and $\mathrm{Na}$ of colostrum were sufficient for newborn yak calves, according to the minerals requirements of diary calves (NRC, 2001), whereas the others were not adequate for their requirement.

In summary, concentrations of nutrients in yak colostrum changed dramatically within $24 \mathrm{~h}$ postpartum. As for $\operatorname{IgG}$, the first $2 \mathrm{~h}$ after parturition were the best time to obtain the highest IgG content from yak colostrum (above $50 \mathrm{mg}$ of $\mathrm{IgG} / \mathrm{mL}$ ). The current results and known neonate bovine intestinal biology suggested that yak colostrum should be provided for calves as soon as possible to help them to obtain adequate nutrients and immune capacity. Data within this report could also be used as a guide for producing milk replacers for yak calves.

\section{ACKNOWLEDGMENTS}

The authors acknowledge financial support from the National Nature Science Foundation of China (31170378; Beijing, China) and the Research Fund for the Doctoral Program of Higher Education (20120211110030; Beijing, China). J. D. Mi thanks the China Scholarship Council (CSC; Beijing, China), who provided a scholarship under the State Scholarship Fund for him to pursue his PhD study in Australia (201406180022). We also thank the farmer Liu Deli who helped collect colostrum samples in this study, as well as Giacomantonio Pete and Padmanabha Jagadish in CSIRO (St. Lucia, QLD, Australia) who helped to revise paper in English.

\section{REFERENCES}

Albalá-Hurtado, S., M. T. Veciana-Nogue, M. Izquierdo-Pulido, and A. Marine. 1997. Determination of water-soluble vitamins in infant milk by high-performance liquid chromatography. J. Chromatogr. A $778: 247-253$

Alves, A. C., N. G. Alves, I. J. Ascari, F. B. Junqueira, A. S. Coutinho, R. R. Lima, J. R. O. Pérez, S. O. De Paula, I. F. FurushoGarcia, and L. R. Abreu. 2015. Colostrum composition of Santa Inês sheep and passive transfer of immunity to lambs. J. Dairy Sci. 98:3706-3716.

AOAC International. 1999. Official Methods of Analysis. AOAC International, Washington, DC.

Arnaud, J., I. Fortis, S. Blachier, D. Kia, and A. Favier. 1991. Simultaneous determination of retinol, $\alpha$-tocopherol and $\beta$-carotene in serum by isocratic high-performance liquid chromatography. J. Chromatogr. 572:103-116.

Castro-Alonso, A., N. Castro, J. Capote, A. Morales-delaNuez, I. Moreno-Indias, D. Sánchez-Macias, P. Herraez, and A. Argüello. 
2008. Short communication: Apoptosis regulates passive immune transfer in newborn kids. J. Dairy Sci. 91:2086-2088.

Coroian, A., S. Erler, C. T. Matea, V. Mireșan, C. Răducu, C. Bele, and C. O. Coroian. 2013. Seasonal changes of buffalo colostrum: Physicochemical parameters, fatty acids and cholesterol variation. Chem. Cent. J. 7:40-48.

Csapo, J., T. G. Martin, Z. S. Csapo-Kiss, and Z. Hazas. 1996. Protein, fats, vitamin and mineral concentrations in porcine colostrum and milk from parturition to 60 days. Int. Dairy J. 6:881-902.

Cui, N., P. C. Wen, Q. Liang, H. N. Liu, W. B. Zhang, P. J. Wang, H. Y. Guo, and F. Z. Ren. 2014. Chemical composition of yak colostrum and transient milk. J. Anim. Physiol. Anim. Nutr. 99:825833. http://dx.doi.org/10.1111/jpn.12282.

Cummins, K. A., and C. J. Brunner. 1991. Effect of calf housing on plasma ascorbate and endocrine and immune function. J. Dairy Sci. 74:1582-1588.

Debier, C., J. Pottier, C. Goffe, and Y. Larondelle. 2005. Present knowledge and unexpected behaviours of vitamins $\mathrm{A}$ and $\mathrm{E}$ in colostrum and milk. Livest. Prod. Sci. 98:135-147.

Ding, L., Y. Wang, M. Kreuzer, X. Guo, J. Mi, Y. Gou, Z. Shang, Y Zhang, H. Wang, and R. Long. 2013. Seasonal variations in the fatty acid profile of milk from yaks grazing on the Qinghai-Tibetan plateau. J. Dairy Res. 80:410-417.

El-Fattah, A. M. A., F. H. A. Rabo, S. M. El-Dieb, and H. A. ElKashef. 2012. Changes in composition of colostrum of Egyptian buffaloes and Holstein cows. BMC Vet. Res. 8:19-26.

Eitenmiller, R. R., W. O. Landen Jr., and L. Ye. 2007. Vitamin Analysis for the Health and Food Sciences. CRC Press, Boca Raton, FL.

Fiske, C. H., and Y. Subbarow. 1925. The colorimetric determination of phosphorus. J. Biol. Chem. 66:375-400.

Foley, J. A., and D. E. Otterby. 1978. Availability, storage, treatment, composition, and feeding value of surplus colostrum: A review. J. Dairy Sci. 61:1033-1060.

Godden, S. 2008. Colostrum management for dairy calves. Vet. Clin. Food Anim. 24:19-39.

Guo, X., R. Long, M. Kreuzer, L. Ding, Z. Shang, Y. Zhang, Y. Yang, and G. Cui. 2014. Importance of functional ingredients in yak milk-derived food on health of Tibetan nomads living under highaltitude stress: a review. Crit. Rev. Food Sci. Nutr. 54:292-302.

Hurley, W. L., and P. K. Theil. 2011. Perspectives on immunoglobulins in colostrum and milk. Nutrients 3:442-474.

Kehoe, S. I., B. M. Jayarao, and A. J. Heinrichs. 2007. A survey of bovine colostrum composition and colostrum management practices on Pennsylvania dairy farms. J. Dairy Sci. 90:4108-4116.

Klimeš, J., P. Jagoš, J. Bouda, and S. Gajdůšek. 1986. Basic qualitative parameters of cow colostrum and their dependence on season and postpartum time. Acta Vet. Brno 55:23-39.
Kume, S.., and S. Tanabe. 1993. Effect of parity on colostral mineral concentrations of Holstein cows and value of colostrum as a mineral source for newborn calves. J. Dairy Sci. 76:1654-1660.

Larson, B. L., H. L. Heary, and J. E. Devery. 1980. Immunoglobulin production and transport by the mammary gland. J. Dairy Sci 63:665-671.

Levieux, D., and A. Ollier. 1999. Bovine immunoglobulin G, $\beta$-lactoglobulin, $\alpha$-lactalbumin and serum albumin in colostrum and milk during the early postpartum period. J. Dairy Res. $66: 421-430$.

Long, R. J., L. M. Ding, Z. H. Shang, and X. S. Guo. 2008. The yak grazing system on the Qinghai-Tibetan plateau and its status. Rangeland J. 30:241-246.

Long, R. J., D. G. Zhang, X. Wang, Z. Z. Hu, and S. K. Dong. 1999. Effect of strategic feed supplementation on productive and reproductive performance in yak cows. Prev. Vet. Med. 38:195-206.

Ma, Y., S. He, and H. Li. 2013. Yak milk. Pages 627-643 in Milk and Dairy Products in Human Nutrition: Production, Composition and Health. Wiley-Blackwell, Chichester, UK.

Marounek, M., L. Pavlata, L. Mišurová, Z. Volek, and R. Dvořák. 2012 Changes in the composition of goat colostrum and milk fatty acids during the first month of lactation. Czech J. Anim. Sci. 57:28-33.

Morrill, K. M., E. Conrad, A. Lago, J. Campbell, J. Quigley, and H. Tyler. 2012. Nationwide evaluation of quality and composition of colostrum on dairy farms in the United States. J. Dairy Sci. 95:3997-4005.

NRC. 2001. Nutrient Requirements of Dairy Cattle. 7th ed. Natl Acad. Sci., Washington, DC.

Park, Y. W., M. Juárez, M. Ramos, and G. F. W. Haenlein. 2007. Physico-chemical characteristics of goat and sheep milk. Small Rumin. Res. 68:88-113.

Romero, T., M. C. Beltrán, M. Rodríguez, A. M. De Olives, and M. P. Molina. 2013. Short communication: Goat colostrum quality: Litter size and lactation number effects. J. Dairy Sci. 96:7526-7531.

Sánchez-Macías, D., I. Moreno-Indias, N. Castro, A. Morales-delaNuez, and A. Argüello. 2014. From goat colostrum to milk: Physical, chemical, and immune evolution from partum to 90 days postpartum. J. Dairy Sci. 97:10-16.

Sukhija, P. S., and D. L. Palmquist. 1988. Rapid method for determination of total fatty acid content and composition of feedstuffs and feces. J. Agric. Food Chem. 36:1202-1206.

Teles, F. F., C. K. Young, and J. W. Stull. 1978. A method for rapid determination of lactose. J. Dairy Sci. 61:506-508.

Wiener, G., J. Han, and R. Long. 2003. The Yak. 2nd ed. FAO Regional Office for Asia and the Pacific, Bangkok, Thailand. 